\title{
The Role of Self-Efficacy and Innovative Work Behaviour in Civil Servants' Work Performance: A Conceptual Paper
}

Renuka Vitapamoorthy, Rosli Mahmood, Hishamuddin Md Som

To Link this Article: http://dx.doi.org/10.6007/IJARBSS/v11-i3/8592

DOI:10.6007/IJARBSS/v11-i3/8592

Received: 31 January 2021, Revised: 25 February 2021, Accepted: 02 March 2021

Published Online: 17 March 2021

In-Text Citation: (Vitapamoorthy et al., 2021)

To Cite this Article: Vitapamoorthy, R., Mahmood, R., \& Som, H. M. (2021). The Role of Self-Efficacy and Innovative Work Behaviour in Civil Servants' Work Performance: A Conceptual Paper. International Journal of Academic Research in Business and Social Sciences, 11(3), 749-761.

Copyright: (c) 2021 The Author(s)

Published by Human Resource Management Academic Research Society (www.hrmars.com)

This article is published under the Creative Commons Attribution (CC BY 4.0) license. Anyone may reproduce, distribute, translate and create derivative works of this article (for both commercial and non-commercial purposes), subject to full attribution to the original publication and authors. The full terms of this license may be seen at: http://creativecommons.org/licences/by/4.0/legalcode

Vol. 11, No. 3, 2021, Pg. 749 - 761

Full Terms \& Conditions of access and use can be found at http://hrmars.com/index.php/pages/detail/publication-ethics 


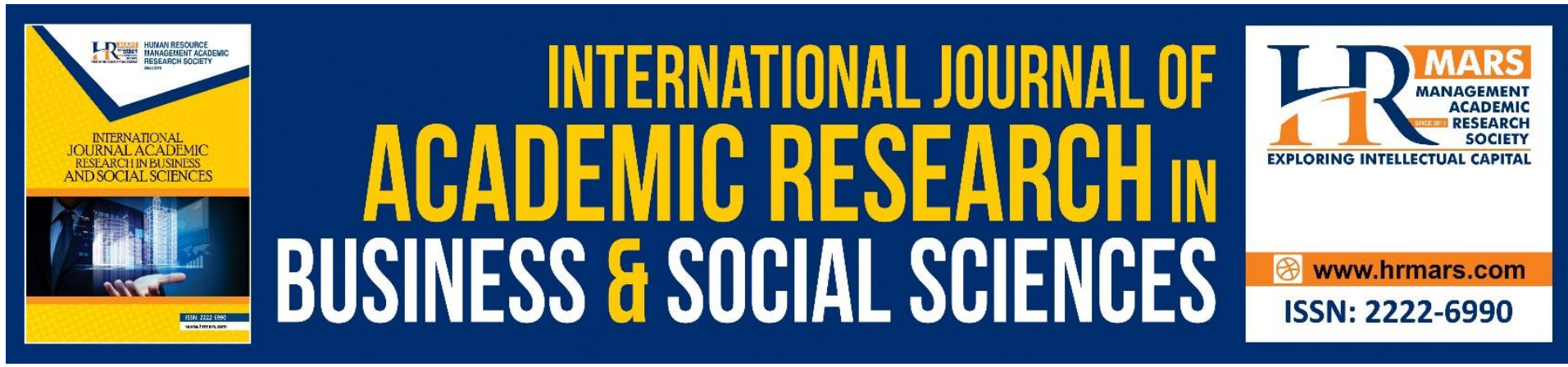

\title{
The Role of Self-Efficacy and Innovative Work Behaviour in Civil Servants' Work Performance: A Conceptual Paper
}

\author{
Renuka Vitapamoorthy, Rosli Mahmood, Hishamuddin Md Som \\ Putra Business School, Serdang 43400, Selangor, Malaysia \\ Email: renuka.phd_mgt17@grad.putrabs.edu.my, rosli@putrabs.edu.my, \\ hishamuddin@putrabs.edu.my
}

\begin{abstract}
This study contributes to the literature on work performance of civil servants by examining the relationship between self-efficacy, work innovative behaviour and its impact on work performance. Social Cognitive Theory was used to as the underpinning theory and a set of hypotheses was formed to test the relationship between self-efficacy and work performance, with work innovative behaviour as a mediator. Research articles, reports and dissertations related to self-efficacy, innovative work behaviour, work performance were reviewed to develop the conceptual model. This study is important in presenting a better insight into how human factors affect work performance as only handful studies have examined the mediating role of innovative work behaviour on the relationship between self-efficacy and work performance within civil servant context.
\end{abstract}

Keywords: Self-Efficacy, Innovative Work Behaviour, Innovation, Work Performance, Civil Servant.

\section{Introduction}

Civil servants need to be competitive and reliable in delivering their services for the social and economic development of a country (Johari and Yahya, 2016). Various factors are noted to mould excellent and competitive civil servants who usually measured in the aspects of skills, knowledge, behaviour, and attitude (Borman, 2004; Borman and Motowidlo, 1997; Organ, 1997; Johari and Yahya, 2016). On the same note, Houston (2000) stated that motivation, leadership style, learner autonomy, and personality traits need to be aligned effectively with work performance for better achievement (Ciobanu and Androniceanu, 2015). Syamsuddin, Kadir and Alam (2020) have also agreed on the aspect of leadership, motivation, and competence as predictors for civil servants' performance. According to Self Cognitive Theory, people can be directed through inner strengths and the environment or by moulding themselves, which all lead to their own motivation, behaviour, and progress (Bandura, 1989). As such, this theory is aligned with the concept of self-efficacy which will be a key motivator for better performance at the workplace.

In the same context, innovative behaviour among employees is also an essential aspect for an organisation to stay competitive (Agarwal, 2014), especially in the public sector. Civil servants 
become a vital asset to the sector and nation when they can generate solutions and ideas and implement them accordingly. Altaf and Atif (2011) expressed that certain skills such as innovativeness can be developed when peacefulness and happiness are internally attained. Work innovative behaviour can be elevated when employees internally motivated, which eventually lead a to better work performance (Afsar and Badir, 2017). Adil, Hamid and Waqas (2020) have further added that intrinsic motivation is more crucial than extrinsic motivation especially in boosting creativity and this showed the importance of embedding self-efficacy in civil servants. Moreover, Self Cognitive Theory has also stated that employees can organise and execute the desired act despite the environment and this act is coined under the concept of this theory (Bandura, 1997; Hamid, Rahid, and Hamid, 2020). Thus, when employees boost inner strengths toward work, better work attributes will be formed including innovative behaviour. Therefore, the existence of the relationship between self-efficacy and work innovative behaviour can be further explored in many areas.

Na-Nan and Sanamthong (2019) emphasized to develop high self-efficacy level among employees in order to high standard of performance. Besides, self-efficacy lead to selfconfidence in the ability to execute certain tasks (Achyar, Nasir, and Musnadi, 2020) and it is important overcome obstacles during the innovation process. Hence, factors like self-efficacy and innovative work behaviour are needed to study civil servants in order to elevate work performance. Many studies have been conducted on the scope of work performance (Eliyana and Sridadi, 2020; Ahmed and Ramzan, 2013; Alessandri, Borgogni, Schaufeli, Caprara and Consiglio, 2015; Jalali and Heidari, 2015; Hamid and Mostafa, 2016; Cao, Guo, Vogel and Zhang, 2016; Moon, Hur and Hyun, 2017; Taba, 2018; Kuvaas, 2008), but there are still limited studies related to the work performance of civil servants.

Considering the amount of effort to improve the work performance of civil servants, many issues arisen from their performance have been highlighted. Table I summarises several findings from past studies related to work performance of civil servants. 
Table I

Summary of studies related to civil servants' work performance.

\begin{tabular}{|l|l|}
\hline Researchers & Key Dimension \\
\hline $\begin{array}{l}\text { Yozgat, Yurtkoru and } \\
\text { Cilginglu (2013) }\end{array}$ & $\begin{array}{l}\text { Job stress and job performance among employees in public sector } \\
\text { in Istanbul: examining the moderating role of emotional } \\
\text { intelligence }\end{array}$ \\
\hline $\begin{array}{l}\text { Androniceanu (2015) } \\
\text { Ermira (2015) }\end{array}$ & $\begin{array}{l}\text { Civil servants motivation and work performance in Romanian } \\
\text { public institutions }\end{array}$ \\
\hline $\begin{array}{l}\text { Johari and Yahya } \\
\text { (2016) }\end{array}$ & $\begin{array}{l}\text { Motivation factors impacting the civil servant performance in local } \\
\text { public administration in Kosovo }\end{array}$ \\
\hline $\begin{array}{l}\text { Mustapa and } \\
\text { Mahmood (2016) }\end{array}$ & $\begin{array}{l}\text { Job characteristics, work involvement, and job performance of } \\
\text { public servants }\end{array}$ \\
\hline $\begin{array}{l}\text { Habba, Modding, Bima } \\
\text { and Bijang (2017) }\end{array}$ & $\begin{array}{l}\text { The effect of leadership, organisational culture and work } \\
\text { motivation on job satisfaction and job performance among civil } \\
\text { servants in Maros District technical working unit }\end{array}$ \\
\hline $\begin{array}{l}\text { Sulaiman, Othman and } \\
\text { Mahboob (2017) }\end{array}$ & $\begin{array}{l}\text { The relationship between organizational culture with job } \\
\text { performance among executive staff in public sector }\end{array}$ \\
\hline $\begin{array}{l}\text { Yuliantini, Lukertina } \\
\text { and Kurniawan (2019) }\end{array}$ & $\begin{array}{l}\text { The influence of physical environment, competence, verbal } \\
\text { communication has influence on employee's performance }\end{array}$ \\
\hline $\begin{array}{l}\text { Syamsuddin et al. } \\
\text { (2020) }\end{array}$ & $\begin{array}{l}\text { The effect of leadership, work motivation and competence on } \\
\text { performance of civil servants }\end{array}$ \\
\hline $\begin{array}{l}\text { Bayram and Zoubi } \\
\text { (2020) }\end{array}$ & $\begin{array}{l}\text { Servant leadership, public service motivation and employee } \\
\text { performance among staff in the context of Jordanian civil servants. }\end{array}$ \\
\hline
\end{tabular}

\section{Literature Review and Hypothesis Development Work Performance of Civil Servants}

As organisations are progressing for better profitability and productivity, performance is becoming the vital key marker to remain pertinent in the worldwide market. However, literatures on improving organisational performance through civil servants' performance are still insufficient (Asif and Rathore, 2021). As indicated by Campbell (1990), conduct or activities that are significant to the objectives of an organisation are defining the concept of work performance. Many scholars have referenced that work performance can be categorised into task performance and contextual performance in many research diaries. Referencing an article composed by Mustapa and Mahmood (2016), Borman and Motowidlo (1993) have characterised task performance as "the proficiency with which job incumbents perform activities that are formally recognised as part of their job, activities that are contributing to the organisation's technical core either directly by implementing a part of its technological process, or indirectly by providing it with needed materials or services" (Borman and Motowidlo, 1993, p.73). Then again, contextual performance is clarified as "discretionary behaviours that apply across all jobs are not necessarily role prescribed and that contribute to the social and psychological environment of the organisation" (Borman and Motowidlo, 1993, p.73). Both task performance and contextual performance are essential to attaining the organisation's desired goal (Black and Porter, 1991; Jahangir, Akbar and Haq, 2004; Johari and Yahya, 2016) especially at the public sectors. 
Various issues related to performance of civil servants have been mentioned by many researchers worldwide. Striteska and Sein (2021) stated that fear of change among civil servants lead to ineffectiveness and lack of efficiency in the civil sectors. Ciobanu and Androniceanu (2015) have reported that several European countries are experiencing issues in retaining professionals from public sectors and also facing stiff competition with the private sectors. Yozgat et al. (2013) mentioned that deadlines and time factors are causing high stress level among civil servants. Siti Saraswati (2017) has also stated the demand for better performance and service delivery are elevating the pressure among civil servants. Yuliantini et al. (2019) have also identified on the issues of communication, career development, and work environment among civil servants in Jakarta. High suicide rate was reported among civil servants in China compared to other professions which is attributed to pressure (Kong, Yang and Zhang, 2020). In the same context, civil servants in Malaysia are also under pressure with the community demand for better performance and accountability. Their weakness have been highlighted by various sources (Hamdan and Norudin, 2010; Mustapa and Mahmood, 2016). Hence, these issues are affecting the performance of civil servants in Malaysia.

Human factors such as capability, drive of employees, and organisational factors including job characteristics and culture need to be evaluated accordingly to elevate performance level (Campbell, 1990; Williams, 2002; Johari and Yahya, 2016). Ciobanu and Androniceanu (2015) have also reiterated that civil servants are motivated by work environment and level of freedom or joy in executing the task. In conjunction, several aspects relating to organisational factors like organisational culture (Sulaiman et al., 2017; Habba et al., 2017), job characteristics (Johari and Yahya, 2016), and knowledge management (Mustapa and Mahmood, 2016) were studied by several scholars. Human factors such as job stress (Yozgat et al., 2013), motivation (Ciobanu and Androniceanu, 2015; Habba et al., 2017), and personality trait (Zahari, 2016) were also examined in relation to work performance of civil servants. For example, Sulaiman et al. (2017) studied the relationship between work performance of civil servants and organisational culture in Putrajaya, Malaysia. The study concluded that the job performance of civil servants is significant and positive with three aspects of organisational culture. On the other hand, study conducted by Habba et al. (2017) showed that organisational culture has a positive but non-significant impact on performance.

\section{The Relationship between Self-Efficacy and Work Performance}

Self-efficacy is defined as "people's judgements of their capabilities to organise and execute courses of action required to attain designated types of performances" (Bandura, 1986, p.391). Social Cognitive Theory explains one's ability to organise and execute the desired behaviour, regardless of the environment (Bandura, 1997; Hamid et al., 2020). As such, this fundamental assumption of the Social Cognitive Theory shows the impact of self-efficacy on work performance. Self-efficacy is a crucial determinant of performance as individuals with a high level of self-efficacy will have a higher degree of tolerance to hurdles from the stress at the workplace (Cherian and Jacob, 2013; Keskin, 2020). Employees with high level of selfefficacy will be able to reduce their levels of stress and anxiety (Liu, Cho and Putra, 2017; Nair and Sivakumar, 2020) and perform at higher expectation level (Na-Nan and Sanamthong, 2019), which eventually lead to better work performance.

In the same note, self-efficacy impacted work performance and it is an ascending determinant to encourage employees for high work performance (Keskin, 2020). In contrast, Beck and 
Shmidt (2015) argued the non-significant relationship between self-efficacy and performance. Similarly, Manasseh (2015) also stated that there is no direct relationship between selfefficacy and work performance based on the reviewed studies. Manasseh (2015) reiterated that self-efficacy may not directly connected to performance based on Social Cognitive Theory. Besides, inducing self-efficacy at the workplace will lead to stress (Lunenburg, 2011) and overconfidence (Vancouver, Thompson, Tischner, and Putka, 2002; Tian, Wang, Zhang, and Wen, 2019)

Thus, self-efficacy may not be a strong factor of efficacy-performance relationship (Bandura, 1986; Bandura, 1990; Proios Fotiadou, Doganis, Batsiou, and Proios, 2020) and the condition on which self-efficacy affects work attitudes and behaviours is important (Hur, Moon and Lee, 2020). Furthermore, only a handful studies examined the direct impact of self-efficacy on the performance of employees although self-efficacy is identified as a crucial predictor of performance (Cherian and Jacob, 2013) and varies across different contexts (Hur et al., 2020).

\section{Work Innovative Behaviour as a Mediator}

Innovative work behaviour was explained by Janssen (2000, p.288) as "the intentional creation, introduction, and application of new ideas within a work role, group, or organisation to benefit role performance, the group, or the organisation". This behaviour enhances employees performance at workplace (Suryani et al., 2019). Researchers have also agreed that innovative work behaviour has affected effectiveness and survival of organisations which are main factors for better performance (Oldham and Cummings, 1996; Scott and Bruce, 1994; Pradhan and Jena, 2019). In the same token, innovation has been proven to improve effectiveness and service delivery in the public sector administrations (Salge and Vera, 2012; Miao, Newman, Schwarz and Cooper, 2018), but only limited studies have been done on the predictors that instigate innovative behaviour in the public sector (Bysted and Hansen, 2015). Besides, Wen, Wu and Long (2021) reiterated that factors that boost worker's innovative behaviour are still the aim of the theoretical and practical areas.

Self-efficacy behaved as a catalyst of innovative behaviour, similar to the behaviour in predicting creativity (Tierney and Farmer, 2011; Mielniczuk and Laguna, 2020). Self-efficacy is also known as a predictor of motivation to be creative and innovative (Bandura, 1977; Tran, Nguyen and Nguyen, 2018). Employees will show innovative behaviour when they know this act leads to positive results at the workplace (van Zyl, van Oort, Rispens and Olckers 2019). However, innovative actions will also lead to significant stress due to obstacles, effort, risks and uncertainty (Wojtczuk-Turek and Turek, 2015). Nonetheless, relatively limited attention has been directed towards understanding the relationship between self-efficacy and work performance with work innovative behaviour as a mediator, especially among the Malaysian civil servants.

Mielniczuk and Laguna (2020) also justified that innovative work behaviour can be rather challenging due to the presence of high failure risk. Thus, Hosseini and Haghighi Shirazi (2021) mentioned that engaging employees will stimulate innovative behaviour. As such, individuals who embrace higher self-efficacy are more likely to try challenging tasks compared to those with lower self-efficacy (Bandura, 1997; Mielniczuk and Laguna, 2020). Besides, Bandura (1999) stated that human mind react and displays creativity, and such act involves strategic behaviour based on the selected desires. Thus, innovative work behaviour is needed in each work execution, which subsequently contributes to one's work performance. This convincingly provides justifications on the mediating role of innovative work behaviour with 
respect to the Social Cognitive Theory. With that, the Social Cognitive Theory was adapted as the underpinning theory to explore innovative work behaviour in the current study.

Besides, Ali and Buang (2016) stated work innovative behaviour is not strongly correlated to innovation compared to innovation climate and participative leadership in their study as civil servants need impactful internal booster to innovate. Mutonyi, Slatten and Lien (2020) have also studied innovative behaviour of public servants in Norway but in the aspects of empowering leadership, work group cohesiveness, individual learning orientation. Similarly, Carlucci, Mura and Schiuma (2020) have studied organisational climate, organisation's openness to innovation with work innovative behaviour on civil servants. However, minimal research connected spirituality as an influencer for civil servants' work innovative behaviour. In fact, Bos-Nehles, Renkema and Janssen (2017) have mentioned that research on work innovative behaviour has demonstrated inconsistent findings. Ali and Buang (2011) also revealed that research on work innovative behaviour are mostly limited to organisational, leader, and innovation process. Hence, exploring work innovative behaviour with performance and spirituality is crucial as it is still under-researched.

\section{The Proposed Model}

This paper proposed a conceptual framework to analyse the effect of self-efficacy on work performance (see Figure I). Although many studies have examined the link between selfefficacy and work performance, there are still inconsistencies in the findings and hypothesis was developed based on these studies. In the same context, the role of innovative work behaviour as a mediator in order to enhance the relationship between self-efficacy and work performance is under-researched. Social Cognitive Theory will be applied in order to conceptualise these relationships.

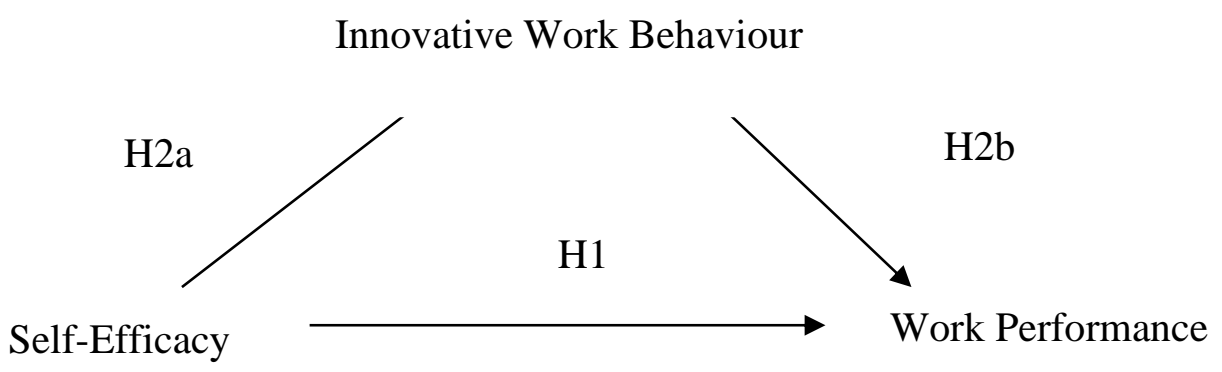

Figure I. Conceptual model with factors that influence work performance

\section{Prepositions}

Based on the above preceding discussions, the following prepositions will be addressed such as:

$\mathrm{H} 1$. There is a relationship between self-efficacy and work performance.

$\mathrm{H} 2$. Work innovative behaviour mediates the relationship between self-efficacy and work performance.

\section{Conclusions}

Self-efficacy and work innovative behavior can be used as a predictor to elevate work performance of civil servants and these findings provide a clearer picture on the internal 
needs of civil servants as a booster to cultivate a more competitive work force among them. When an individual is able to handle their task efficiently, the performance level can be elevated especially in the government sectors. In the same context, self-efficacy will lead individual to organise and execute their task in the workplace. Thus, civil servants have better vision and goals in their career and contribute to better performance at the workplace. This internal booster will motivate civil servants to overcome hurdles in the workplace and perform their task in an efficient manner. Besides that, civil servants should develop an internal motivator through self-efficacy in order to mould innovative behaviour which enhances work performance. Apart from, human factor plays an important role in order to effectively progress in attaining success. This serves to be a wakeup call for practitioners in focusing human factors especially among civil servants. Not only that, work performances of civil servants still a mildly explored area by researchers. This capability and skills can be seen as an innovative behaviour for better personal enhancement among civil servants. Conclusively, self-efficacy influences the work performance of civil servants though innovative behaviour. The findings from this study are crucial as limited studies have investigated the relationship between self-efficacy and work performance with work innovative behaviour as a mediator.

\section{References}

Achyar, D. M., Nasir, \& Musnadi, S. (2020). The Effect of Skill, Self Evaluation and Locus of Control on Employee Performance with Self Efficacy as a Mediation Study in PT. Angkasa Pura II SIM Airport Office. International Journal of Scientific and Management Research, 3(2), 192-206.

Adil, M. S., Hamid, K. B. A., \& Waqas, M. (2020). Impact of perceived organisational support and workplace incivility on work engagement and creative work involvement: a moderating role of creative self-efficacy. Int. J. Management Practice, 13(2), 117-150.

Afsar, B., \& Badir, Y. (2017). Workplace spirituality, perceived organizational support and innovative work behavior: The mediating effects of person-organization fit. Journal of Workplace Learning, 29(2), 95-109, https://doi.org/10.1108/JWL-11-2015-0086

Agarwal, U. A. (2014). Examining the impact of social exchange relationships on innovative work behaviour: Role of work engagement. Team Performance Management, 20(3-4), 102-120. https://doi.org/10.1108/TPM-01-2013-0004

Ahmed, A., \& Ramzan, M. (2013). Effects of Job Stress on Employees Job Performance: A Study on Banking Sector of Pakistan. IOSR Journal of Business and Management, 11(6), 61-68. https://doi.org/10.9790/487x-1166168

Alessandri, G., Borgogni, L., Schaufeli, W. B., Caprara, G. V., \& Consiglio, C. (2015). From Positive Orientation to Job performance: The Role of Work Engagement and Self-efficacy Beliefs. Journal of Happiness Studies, 16(3), 767-788. https://doi.org/10.1007/s10902014-9533-4

Ali, K. A. M., \& Buang, M. (2016). Study on Factors that Influence Innovation in Malaysian Public Sector. Journal of Advanced Research in Business and Management Studies ISSN, 4(1), 60-73.

Altaf, A., \& Atif, M. (2011). Moderating Effect of Workplace Spirituality on the Relationship of Job Overload and Job Satisfaction. Journal Business Ethics. 104, 93-99. https://doi.org/10.1007/s10551-011-0891-0

Asif, A., \& Rathore, K. (2021). Behavioral Drivers of Performance in Public-Sector Organizations: A Literature Review. SAGE Open, 11(1). 
Bandura, A. (1977). Self-efficacy: Toward a unifying theory of behavioral change. Psychological Review, 84(2), 191-215.

Bandura, A. (1986). Social foundations of thought and action: A social cognitive theory. Englewood Cliffs.

Bandura, A. (1989). Social cognitive theory. In R. Vasta (Ed.), Annals of child development. Vol.6. Six theories of child development (pp. 1-60). JAI Press.

Bandura, A. (1990). Conclusion: Reflections on non-ability determinants of competence. In sternberg, r. And kolligian, j. (eds.), competence considered (pp. 315-62). Yale University Press.

Bandura, A. (1997). Self-efficacy: The exercise of control. Freeman.

Bandura, A. (1999). Social Cognitive Theory: An agentic perspective. Asian Journal of Psychology, 2, 21-41.

Bayram, P., \& Zoubi, K. (2020). The effect of servant leadership on employees' self-reported performance: Does public service motivation play a mediating explanatory role?.Management Science Letters, 10(8), 1771-1776.

Beck, J. W., \& Schmidt, A. M. (2018). Negative Relationships Between Self-Efficacy and Performance Can Be Adaptive: The Mediating Role of Resource Allocation. Journal of Management, 44(2), 555-588. https://doi.org/ 10.1177/0149206314567778

Black, J. S., \& Porter, L. W. (1991). Managerial behaviours and job performance: a successful manager in Los Angeles may not succeed in Hong Kong. Journal of International Business Studies, 22(1), 99-113.

Borman, W. C., \& Motowidlo, S. J. (1997). Organizational citizenship behavior and contextual performance. Human Performance, 10(2), 67-70.

Borman, W. C. (2004). Introduction to the special issue: personality and the prediction of job performance: more than the big five. Human Performance, 17(3), 267-269.

Borman,W. C., \& Motowidlo, S. J. (1993). Expanding the criterion domain to include elements of contextual performance, in Schmitt, N. and Borman, W.C. (Eds), Personnel Selection in Organizations, (pp. 71-98). Jossey Bass, San Francisco, CA

Bos-Nehles, A., Renkema, M., \& Janssen, M. (2017). HRM and innovative work behaviour: a systematic literature review. Personnel Review, 46(7) 1228-1253. https://doi.org/10.1108/PR-09-2016-0257

Bysted, R., \& Hansen, J. R. (2015). Comparing Public and Private Sector Employees' Innovative Behaviour: Understanding the Role of Job and Organizational Characteristics, Job Types, and Subsectors. Public Management Review, 17(5), 698 - 717.

Campbell, J. P. (1990). Modeling the performance prediction problem in industrial and organizational psychology. In M.D. Dunnette, M.D. and L.M. Hough (Eds), Handbook of Industrial and Organizational Psychology (pp.687-732). Consulting Psychologists Press.

Cao, X., Guo, X., Vogel, D., \& Zhang, X. (2016). Exploring the influence of social media on employee work performance. Internet Research, 26(2), 529-545. https://doi.org/10.1108/IntR-11-2014-0299

Carlucci, D., Mura, M. \& Schiuma, G. (2020). Fostering Employees; Innovative Work Behaviour in Healthcare Organisations. International Journal of Innovation Management, 24(2).

Cherian, J., \& Jacob, J. (2013). Impact of Self Efficacy on Motivation and Performance of Employees. International Journal of Business and Management, 8(14), 80-88. https://doi.org/10.5539/ijbm.v8n14p80 
Ciobanu, A., \& Androniceanu, A. (2015). Civil Servants Motivation and Work Performance in Romanian Public Institutions. Procedia Economics and Finance, 30(15), 164-174. https://doi.org/10.1016/s2212-5671(15)01280-0

Eliyana, A., \& Sridadi, A. (2020). Workplace spirituality and job satisfaction toward job performance: The mediation role of workplace deviant behavior and workplace passion. Management Science Letters, 10(11), 2507-2520.

Habba, D., Modding, B., Bima, M. J., \& Bijang, J. (2017). The Effect of Leadership, Organisational Culture and Work Motivation on Job Satisfaction and Job Performance among Civil Servants in Maros District Technical Working Unit. IRA-International Journal of Management \& Social Sciences (ISSN 2455-2267), 7(1), 52. https://doi.org/10.21013/jmss.v7.n1.p7

Hamdan \& Norudin. (2010) Customers' Satisfaction towards Counter Service of Local Authority in Terengganu, Malaysia. Asian Social Science (v6),197.

Hamid, R. A., Rahid, M. R., \& Hamid, S. N. A. (2020). The effects of employee participation in creative-relevant process and creative self-efficacy on employee creativity. Malaysian Journal of Society and Space, 16 (2), 179-191

Hamid, T., \& Mostafa, Z. (2016). Examine the effect of individual creativity on job performance with mediating role of ethical leadership of headquarters staff of Hormozgan University of Medical Sciences. International Business Management, 10(8), 1427-1433.

Hosseini, S., \& Shirazi, H. Z. R. (2021). Towards teacher innovative work behavior: A conceptual model. Cogent Education, 8(1), 1869364.

Houston, D. J. (2000). Public-service motivation: a multivariate test, Journal of Public Administration Research and Theory, 10(4), 713-27.

Hur, W. M., Moon, T. W., \& Lee, J.H. (2020). The effect of self-efficacy on job performance through creativity: the moderating roles of customer incivility and service scripts. Asia Pacific Journal of Marketing and Logistics. 1355-5855.

Jahangir, N., Akbar, M. M., and Haq, M. (2004). Organizational citizenship behavior: its nature and antecedents', BRAC University Journal, 1(2), 75-85.

Jalali, Z., \& Heidari, A. (2015). The Relationship Between Happiness, Creativity And Job Performance Of Primary School. Indian Journal of Fundamental and Applied Life Sciences, 5(S4), 772-778.

Janssen, O. (2000). Job demands, perceptions of effort-reward fairness and innovative work behaviour. Journal of Occupational and Organizational Psychology, 73(3), 287-302.

Johari, J., \& Yahya, K. K. (2016). Job characteristics, work involvement, and job performance of public servants. European Journal of Training and Development, 40(7), 554-575. https://doi.org/10.1108/EJTD-07-2015-0051

Keskin, E. (2020). Relationships among Self-efficacy, Job Resourcefulness and Job Performance of Hotel Cooks in Cappadocia. Journal of Multidisciplinary Academic Tourism, 5(1), 17-27.

Kong, W., Yang, Y., \& Zhang, F. (2020). Mediating role of occupational stress and job satisfaction on the relationship between neuroticism and quality of life among Chinese civil servants: a structural equation model. Health Qual Life Outcomes 18, 34.

Kuvaas, B. (2008). A test of hypotheses derived from self-determination theory among public sector employees. Employee Relations, 31(1), 39-56. https://doi.org/10.1108/01425450910916814

Liu, J., Cho, S., \& Putra, E. D. (2017). The moderating effect of self-efficacy and gender on work engagement for restaurant employees in the United States. International Journal of 
Contemporary Hospitality Management, 29(1), 624-642. https://doi.org/10.1108/IJCHM-10-2015-0539

Lunenburg, F. (2011). Self-Efficacy in the Workplace: Management. Academy of Management Review, 12(3).

Manasseh N. I. (2015). Self-Efficacy and Work Performance: A Theoretical Framework of Albert Bandura's Model, Review of Findings, Implications and Directions for Future Research. Psychology and Behavioral Sciences. 4(4), 170-173.doi: 10.11648/j.pbs.20150404.15

Miao, Q., Newman, A., Schwarz, G., \& Cooper, B. (2017). How Leadership and Public Service Motivation Enhance Innovative Behavior. Public Administration Review, 78(1), 71-81. https://doi.org/10.1111/puar.12839

Mielniczuk, E., \& Laguna, M. (2020). Positive Affect Mediates the Relationship Between Selfefficacy and Innovative Behavior in Entrepreneurs. The Journal of Creative Behavior, 54(2), 267-278.

Moon, T. W., Hur, W., \& Hyun, S. S. (2017). How Service Employees' Work Motivations Lead to Job Performance: the Role of Service Employees' Job Creativity and Customer Orientation. Current Psychology. https://doi.org/10.1007/s12144-017-9630-8

Mustapa, A. N., \& Mahmood, R. (2016). Knowledge management and job performance in the public sector: The mediating role of public service motivation. Journal for Studies in Management and Planning, 2(7), 144-164.

Mutonyi, B. R., Slåtten, T., \& Lien, G. (2020). Empowering leadership, work group cohesiveness, individual learning orientation and individual innovative behaviour in the public sector: empirical evidence from Norway. International Journal of Public Leadership, 16(2), 175-197. https://doi.org/10.1108/IJPL-07-2019-0045

Naim, I., Krasniqi, I., \& Ermira, Q. (2015). Motivation Factors Impacting the Civil Servant Performance in Local Public Administration in Kosovo. Journal of US-China Public Administration, 12(1), 15-24. https://doi.org/10.17265/1548-6591/2015.01.002

Nair, R. S., \& Sivakumar, V. (2020). Knowledge Sharing: Will it Enhance the Link between SelfEfficacy and Workplace Spirituality?. International Journal of Management and Humanities (IJMH,) 4(9).

Na-Nan, K., \& Sanamthong, E. (2019). Self-efficacy and employee job performance: Mediating effects of perceived workplace support, motivation to transfer and transfer of training. International Journal of Quality \& Reliability Management, 37(1), 117. https://doi.org/10.1108/IJQRM-01-2019-0013.

Oldham, G. R., \& Cummings, A. (1996). Employee creativity: Personal and contextual factors at work. Academy of Management Journal, 39(3), 607-634.

Organ, D. W. (1997). Organizational citizenship behavior: it's construct cleanup time. Human Performance, 10(2), 85-97.

Pradhan, S., \& Jena, L. K. (2019). Does Meaningful Work Explains the Relationship Between Transformational Leadership and Innovative Work Behaviour? The Journal for Decision Makers, 44(1), 30-40.

Proios, I., Fotiadou, E., Doganis, G., Batsiou, S., \& Proios, M. (2020). Influence of SelfLeadership Strategies on the Beliefs of General Self-Efficacy. The Journal of Social Sciences Research, 6(5), 531-535.

Salge, T. O., \& Vera, A. (2012). Benefiting from Public Sector Innovation: The Moderating Role of Customer and Learning Orientation. Public Administration Review, 72 (4), $550-60$. 
Scott, S. G., \& Bruce, R. A. (1994). Determinants of innovative behavior: A path model of individual in the workplace. Academy of Management Journal, 37(3), 580-607.

Siti Sarawati, H. J. (2017). Kecerdasan Emosi, Estim Kendiri dan Komitmen terhadap Organisasi; Kesan dan Pengaruh di Kalangan Penjawat Awam. Penerbit Uthm, 9(1), 1-13.

Sulaiman, W. I. W., Othman, N. F., \& Mahbob, M. H. (2017). Hubungan Pengkomunikasian Budaya Organisasi Dengan Prestasi Kerja Kakitangan Pelaksana Sektor Awam. Journal of Social Sciences and Humanities, 12(3).

Suryani, I., Armia, S., Halimatussakdiah, H., Mahdani, M., Zuhra, S. E., \& Nasir, N. (2019). How Intrinsic Motivation and Innovative Work Behavior Affect Job Performance, 292(Agc), 606-612. https://doi.org/10.2991/agc-18.2019.91

Syamsuddin, S., Kadir, A., \& Alam, S. (2020). Improving Performance Of Civil Servants: The Effect Of Leadership, Work Motivation And Competence. Hasanuddin Journal of Applied Business and Entrepreneurship, 3(1), 1-6.

Taba, M. I. (2018). Mediating effect of work performance and organizational commitment in the relationship between reward system and employees' work satisfaction. Journal of Management Development, 37(1), 65-75. https://doi.org/10.1108/JMD-11-2016-0256

Tian, G., Wang, J., Zhang, Z., \& Wen, Y. (2019). Self-efficacy and work performance: The role of work engagement. Social Behavior and Personality: An international journal, 47(12), e8528.

Tierney, P., \& Farmer, S. M. (2011). Creative self-efficacy development and creative performance over time. Journal of Applied Psychology, 96, 277-293. https://doi.org/10.1037/a0020952.

Tran, K. T., Nguyen, P. V., \& Nguyen, L. M. (2018). The Role of Financial Slack, Employee Creative Self-Efficacy and Learning Orientation in Innovation and Organizational Performance. Administrative Sciences, 8, 82.

van Zyl, L. E., van Oort, A., Rispens, S., \& Olckers, C. (2019). Work engagement and task performance within a global Dutch ICT-consulting firm: The mediating role of innovative work behaviors. Current Psychology. 1-12.

Vancouver, J. B., Thompson, C. M., Tischner, E. C., \& Putka, D. J. (2002). Two studies examining the negative effect of self-efficacy on performance. Journal of Applied Psychology, 87, 506-516. https://doi.org/10.1037/0021-9010.87.3.506

Wen, Q., Wu, Y., \& Long, J. (2021). Influence of Ethical Leadership on Employees' Innovative Behavior: The Role of Organization-Based Self-Esteem and Flexible Human Resource Management. Sustainability, 13(3), 1359.

Williams, R. S. (2002), Managing Employee Performance: Design and Implementation in Organizations, Thompson Learning, London.

Wojtczuk-Turek, A., \& Turek, D. (2015). Innovative behaviour in the workplace: The role of HR flexibility, individual flexibility and psychological capital: the case of Poland. European Journal of Innovation Management, 18(3), 397-419. https://doi.org/10.1108/EJIM-032014-0027

Yozgat, U., Yurtkoru, S., \& Bilginoğlu, E. (2013). Job Stress and Job Performance Among Employees in Public Sector in Istanbul: Examining the Moderating Role of Emotional Intelligence. Procedia - Social and Behavioral Sciences, 75, 518-524. https://doi.org/10.1016/j.sbspro.2013.04.056

Yuliantini, T., Lukertina, L., \& Kurniawan, D. (2019). Determinant Factors of Civil Servants' Performance, Advances in Economics, Business and Management Research, 120. 
INTERNATIONAL JOURNAL OF ACADEMIC RESEARCH IN BUSINESS AND SOCIAL SCIENCES

Vol. 11, No. 3, 2021, E-ISSN: 2222-6990 @ 2021 HRMARS

Zahari, N. A. (2016). Personality traits and differences of generations: do they affect the public servants' job performance? Journal of Global Business and Social Entrepreneurship, 2(4), 12-21. 